\title{
Use of the lignin-ratio technique for determining the extent of digestion in the reticulo-rumen of the cow
}

\author{
By C. C. BALCH \\ National Institute for Research in Dairying, University of Reading \\ (Received 29 November 1956)
}

\begin{abstract}
Although the great importance of the digestive processes taking place in the reticulorumen is accepted without question, surprisingly little is known of their extent. Both breakdown and absorption of food occur in the reticulo-rumen, but there are also microbial synthesis and addition of substances from saliva, and a reliable method of determining the overall balance of outflow of various components of the diet from the reticulo-rumen over the intake of these substances as food would be of considerable value. A measure of the balance for the entire digestive tract is given by digestibility coefficients based on the weight and composition of the faeces, but it is well known that the values for some constituents are apparent rather than real. These digestibility coefficients for the entire tract have frequently been obtained by determining the ratio of a given food constituent to some indigestible marker in the food itself, such as lignin, and the ratio of the constituent to the marker in the faeces. From them the percentage of the nutrient digested is
\end{abstract}

$$
100-\left(100 \times \frac{\text { lignin in food }(\%)}{\text { lignin in faeces }(\%)} \times \frac{\text { nutrient in faeces }(\%)}{\text { nutrient in food }(\%)}\right)
$$

The method does not require a quantitative collection of faeces provided representative samples can be obtained.

Application of this technique to the reticulo-rumen requires a suitable marker and a means of obtaining representative samples of the digesta leaving the reticulo-rumen. In the attempts that have already been made to study this subject the marker selected has usually been the lignin of the diet. The criticism of lignin as a marker on the grounds of its possible digestibility need be no serious objection, since the digestibility can be checked by analysing the faeces. In previous work on this subject the samples of reticulo-rumen contents for analysis were obtained either from fistulated animals by complete removal of the contents (Hale, Duncan \& Huffman, 1940, 1947 $a, b$ ) or by slaughter of the animal and subsequent examination of the gut contents (Gray, 1947; Gray \& Pilgrim, I956; Paloheimo, Mäkelä \& Salo, I955). It is surprising that greater use has not been made of abomasal fistulas.

The results obtained by Hale et al. (1940, 1947a,b) showed that after about $12 \mathrm{~h}$ there was little change in the concentration of lignin in the contents of the reticulorumen of fistulated cows receiving lucerne hay either alone or with beet pulp. From a consideration of the rate of passage of foods through the digestive tract of cows (Balch, 1950) it seems unlikely that all the digesta leaving the reticulo-rumen will have 
this final concentration, or that after $\mathrm{I} 2 \mathrm{~h}$ there will be no further digestion in the reticulo-rumen. Since this conception contradicts the arguments on which the sampling technique used by Hale et al. (1940, 1947 $a, b$ ) was based, the values obtained by them must be treated with caution. Further points have been raised by Paloheimo et al. (1955) in a sharp criticism of the method. However, the mean digestibility coefficients for several analytical fractions of the diet obtained by Hale et al. (1947b) for eight trials at $\mathrm{I}^{2-\mathrm{I}} 4 \mathrm{~h}$ after feeding are within the range found in the experiments now to be described.

Using the lignin-ratio method on digesta from different regions of the digestive tract of sheep, Gray (1947) studied the progress of cellulose digestion along the gut and obtained good agreement between the values for each of four sheep. Paloheimo et al. (1955) have pointed out that the time of slaughter may have influenced these results and that it was possibly unwise to use the whole contents of the omasum for determining the extent of digestion in the reticulo-rumen. The values obtained suggested that on the average $42.7 \%$ of the dietary cellulose had been digested when the digesta reached the abomasum and $58 \cdot 8 \%$ by the time they had reached the colon.

In fourteen cows and five young bulls, receiving various levels of hay in three meals daily and slaughtered $4 \mathrm{~h}$ after feeding, Paloheimo et al. (1955) and Mäkelä (1956) studied the digestion of ' $N$-free organic matter' and ' $N$-free non-lignin organic matter' in the ruminant stomach. Importance was attached to the need to slaughter the animal midway between feeding times. Application of the lignin-ratio technique to samples of digesta from the abomasum showed that of the total amount of $\mathrm{N}$-free non-lignin organic matter digested in the whole gut $76-99 \%$ was digested in the reticulo-rumen and omasum ('proventriculi'); if the results for two of the fourteen cows were discarded the range was $85-91 \%$. On this basis it was concluded that, in cattle, carbohydrates are digested and their degradation products absorbed mainly in the proventriculi. The method used by Gray (1947) and Paloheimo et al. (1955) is not generally applicable, because of the need for slaughter. Though it cannot be disputed that with a diet of hay the method gave highly reproducible results, it can be contended that with other diets, for example diets of hay and concentrates, some other slaughter time would be necessary if the contents of the abomasum were to be representative of the undigested residues leaving the proventriculi.

In the experiments to be reported here a third method has been used to obtain samples from which to calculate digestibility coefficients for the reticulo-rumen by the lignin-ratio method. These experiments were made on cows with rumen fistulas large enough to allow the passage of the arm. 'The opening and closing of the reticuloomasal orifice is a continuous process night and day (Balch, Kelly \& Heim, I95I) and although the rate of opening will vary with different activities of the animal (Balch, 1952) the arrangement of the several periods of each activity through the day gives a fairly even mean rate of movement except during eating when there is a considerable acceleration. It appears likely, therefore, that digesta leave the reticulo-rumen in regular small amounts governed by the rate of opening of the reticulo-omasal orifice. Phillipson (1952) found that in sheep the flow of digesta from the abomasum appeared to be a relatively continuous process. The sampling procedure used in my experiments 
was accordingly based on these observations and on the assumption that on average the digesta lying in the reticulum close beside the reticulo-omasal orifice will have a composition closely similar to the digesta passing through the orifice. Samples of the digesta near the orifice were taken at frequent intervals and then combined and the lignin-ratio technique was applied to the composition of the combined sample.

In the reticulo-rumen there occur, often simultaneously, the processes of intake, passage, absorption, fermentation, addition of saliva, synthesis and, possibly, the transfer of small amounts of substances from the blood. The extent to which any coefficients of apparent digestibility in the reticulo-rumen will reflect processes other than those of breakdown and absorption will vary with different analytical fractions of the food. Thus among the more conventional fractions a coefficient for crude fibre would be almost entirely the result of chemical breakdown. By contrast a coefficient for crude protein (preferably expressed as nitrogen) would show the balance, over the intake in the food, of the processes of breakdown, absorption of ammonia and the addition of urea in saliva. This balance would be affected by the synthesis of nitrogenous compounds from simple sources by the microflora. Similar complications would be attached to values for the mineral constituents (ash) of the diet, and to a lesser degree to the ether-extractable substances and the nitrogen-free extract. These complications have been fully realized by other workers in the field. Thus Hale $e t$ al. $(1947 b)$ determined the fatty-acid and cellulose content of their samples in addition to the conventional fractions. Gray (1947) studied only the digestibility of cellulose and Paloheimo et al. (1955) limited themselves to carbohydrate fractions. The results of my experiments are presented, therefore, not as estimates of the true digestion in the reticulo-rumen, except perhaps for crude fibre, but as examples of the values obtained by application of the lignin-ratio technique to samples thought to be representative of the digesta leaving the reticulo-rumen in a given period. For the reasons given above, it is clearly important that these results should be referred to as apparent digestibility coefficients. If a means of checking the accuracy of this method were devised it might be possible to supplement the analytical procedures with others of greater precision which would give more detailed information about true digestion, synthesis and absorption. Such work has begun, but details are not included here. The best check would appear to be against samples obtained from an abomasal fistula, but none has yet been available in cattle.

In all the experiments now reported the total (henceforth called faecal) digestion was measured by the collection of faeces. It has been possible, therefore, to arrive at estimates of the digestibility and amounts digested in the reticulo-rumen and in the remainder of the digestive tract (or hind gut).

\section{METHODS}

Experimental details. Five experiments were done, each involving one to four fistulated Shorthorn cows. Other aspects of Exps. I, 2 (Balch, 1950) and 3 (Balch, Balch, Bartlett, Bartrum, Johnson, Rowland \& Turner, 1955) have already been reported. The cow were given a range of diets, chosen for various unrelated reasons. They were all based on hay in various amounts and with different supplements. It is regretted that more 
experiments were not conducted on hay alone. The amounts of the different foods given are shown in Tables 3 and 4 . The mean daily intake of the conventional analytical fractions is given in Table I. The hays used in the experiments had been made from ley grasses and were of average quality. The ground hay was produced by passing the hay through a large hammer mill fitted with a fine sieve. The concentrates given in Exp. 2 consisted of dried skim milk and maize starch in equal proportions rendered palatable by molasses. Those given in Exps. 3 and 4 consisted of flaked maize ro, fine wheat offal 7 and decorticated groundnut cake 3 parts with $0.5 \%$ of a commercial mineral mixture. The additional food in Exp. 5 was dried sugar-beet pulp. The straw pulp used in Exp. 3 was dried delignified straw in a finely macerated state. The cows were given their daily allowances of food in two equal portions at intervals of $\mathrm{i} 2 \mathrm{~h}$.

Table I. Mean daily intake (lb.) of the main analytical fractions of the diet by each of the cows on the five experiments

\begin{tabular}{|c|c|c|c|c|c|c|c|c|c|}
\hline $\begin{array}{l}\text { Exp. } \\
\text { no. }\end{array}$ & No. & $\underbrace{\text { art }}_{\begin{array}{c}\text { Length } \\
\text { (days) }\end{array}}$ & Cow & $\begin{array}{c}\text { Dry } \\
\text { matter }\end{array}$ & $\begin{array}{l}\text { Crude } \\
\text { protein }\end{array}$ & $\begin{array}{l}\text { Ether } \\
\text { extract }\end{array}$ & $\begin{array}{l}\text { Nitrogen- } \\
\text { free } \\
\text { extract }\end{array}$ & $\begin{array}{l}\text { Crude } \\
\text { fibre }\end{array}$ & Ash \\
\hline I & $\begin{array}{l}1 \\
2\end{array}$ & $\begin{array}{l}10 \\
10\end{array}$ & $\begin{array}{l}\text { W. } 22 \\
\text { W. } 22\end{array}$ & $\begin{array}{l}12 \cdot 9 \\
18 \cdot 2\end{array}$ & $\begin{array}{l}I \cdot 01 \\
I \cdot 80\end{array}$ & $\begin{array}{l}0.18 \\
0.20\end{array}$ & $\begin{array}{l}6 \cdot 25 \\
9 \cdot 92\end{array}$ & $\begin{array}{l}4.67 \\
4.02\end{array}$ & $\begin{array}{l}0.82 \\
2.25\end{array}$ \\
\hline 2 & $\begin{array}{l}2 \\
1 \\
1 \\
2\end{array}$ & $\begin{array}{l}12 \\
12 \\
12 \\
12\end{array}$ & $\begin{array}{l}\text { W. } 22 \\
\text { W. } 22 \\
\text { H } \\
\text { H }\end{array}$ & $\begin{array}{l}13 \cdot 7 \\
13 \cdot 0 \\
21 \cdot 4 \\
21 \cdot 9\end{array}$ & $\begin{array}{l}0.97 \\
0.94 \\
2 \cdot 10 \\
2 \cdot 1\end{array}$ & $\begin{array}{l}0.18 \\
0.18 \\
0.18 \\
0.18\end{array}$ & $\begin{array}{r}7.17 \\
6.82 \\
\times 3.45 \\
\times 3.88\end{array}$ & $\begin{array}{l}4 \cdot 62 \\
4 \cdot 39 \\
4 \cdot 46 \\
4 \cdot 48\end{array}$ & $\begin{array}{l}0.73 \\
0.72 \\
I \cdot 21 \\
I \cdot 21\end{array}$ \\
\hline 3 & $\begin{array}{l}\text { I } \\
\text { I } \\
2 \\
2 \\
3 \\
3\end{array}$ & $\begin{array}{l}7 \\
7 \\
7 \\
7 \\
7 \\
7\end{array}$ & $\begin{array}{l}\text { D. } 15 \\
\text { H } \\
\text { D. } 15 \\
\text { H } \\
\text { D. } 15 \\
\text { H }\end{array}$ & $\begin{array}{l}28 \cdot 6 \\
30 \cdot 1 \\
22 \cdot 3 \\
22 \cdot 3 \\
23 \cdot 8 \\
23 \cdot 8\end{array}$ & $\begin{array}{l}4 \cdot 97 \\
5 \cdot 13 \\
4 \cdot 12 \\
4 \cdot 12 \\
3 \cdot 24 \\
3 \cdot 24\end{array}$ & $\begin{array}{l}0.82 \\
0.84 \\
0.83 \\
0.83 \\
0.59 \\
0.59\end{array}$ & $\begin{array}{l}16.06 \\
16.65 \\
14.56 \\
14.56 \\
14.01 \\
14.01\end{array}$ & $\begin{array}{l}5 \cdot I I \\
5 \cdot 78 \\
I \cdot 80 \\
I \cdot 80 \\
4 \cdot 88 \\
4 \cdot 88\end{array}$ & $\begin{array}{l}1.63 \\
1.74 \\
0.99 \\
0.99 \\
1.04 \\
1.04\end{array}$ \\
\hline 4 & $\begin{array}{l}I \\
I \\
2 \\
2\end{array}$ & $\begin{array}{l}7 \\
7 \\
7 \\
7\end{array}$ & $\begin{array}{l}\text { D. } 15 \\
\text { L. } 32 \\
\text { D. I5 } \\
\text { L. } 32\end{array}$ & $\begin{array}{l}26 \cdot 5 \\
27 \cdot 3 \\
30 \cdot 6 \\
3 I \cdot r\end{array}$ & $\begin{array}{l}4 \cdot 18 \\
4 \cdot 10 \\
5 \cdot 08 \\
5 \cdot 16\end{array}$ & $\begin{array}{l}0.63 \\
0.61 \\
0.84 \\
0.85\end{array}$ & $\begin{array}{l}15.92 \\
16.05 \\
17 \cdot 48 \\
17.76\end{array}$ & $\begin{array}{l}4 \cdot 26 \\
4 \cdot 89 \\
5 \cdot 36 \\
5 \cdot 45\end{array}$ & $\begin{array}{l}I \cdot 52 \\
I \cdot 63 \\
I \cdot 86 \\
I \cdot 90\end{array}$ \\
\hline 5 & $\begin{array}{l}I \\
I \\
I \\
I\end{array}$ & $\begin{array}{l}10 \\
10 \\
10 \\
10\end{array}$ & $\begin{array}{l}\text { D. } 15 \\
\text { K. } \\
\text { W. } 22 \\
\text { L. } 32\end{array}$ & $\begin{array}{l}16 \cdot I \\
16 \cdot I \\
14 \cdot 9 \\
16 \cdot I\end{array}$ & $\begin{array}{l}r \cdot 26 \\
I \cdot 26 \\
x \cdot 19 \\
x \cdot 26\end{array}$ & $\begin{array}{l}0.17 \\
0.17 \\
0.15 \\
0.17\end{array}$ & $\begin{array}{l}9 \cdot 53 \\
9 \cdot 53 \\
8 \cdot 84 \\
9 \cdot 53\end{array}$ & $\begin{array}{l}4 \cdot 16 \\
4 \cdot 16 \\
3 \cdot 79 \\
4 \cdot 16\end{array}$ & $\begin{array}{l}1 . \infty 0 \\
1.00 \\
0.94 \\
1.00\end{array}$ \\
\hline
\end{tabular}

The cows wore harness for the separate collection of faeces and urine, except in Exp. I when the faeces were collected from the floor. The methods of carrying out digestibility trials were as described in previous publications (e.g. Balch et al. 1955). Lignin was determined by the method of Armitage, Ashworth \& Ferguson (1948) since a preliminary investigation (Balch, Balch \& Rowland, 1954) indicated that it was the most suitable for the purpose, mean digestibility coefficients in one series of eight trials on cows being $4.7 \pm 0.6$ and in ten further trials $-0.72 \pm 0.7$.

Sampling of digesta leaving the reticulo-rumen. For periods of $7^{-12}$ days representing the whole of the collection period in Exps. I, 2 and 5, and the second half of those in Exps. 3 and 4 , the digesta lying in the region of the reticulo-omasal orifice were sampled at frequent intervals. Three samples were taken daily at intervals of $4 \mathrm{~h}$, the time of the 
first sample being chosen at random between 06.00 and $09.00 \mathrm{~h}$ and the samples being arranged during the collection period to give an even spread over the $12 \mathrm{~h}$. In Exps. I and 2 the digesta were also sampled at night, but since these samples gave values similar to those for the day period the practice was discontinued. In Exp. 5 the frequency of sampling was doubled during the period of eating on account of the accelerated flow of digesta from the reticulo-rumen at this time (Balch, 1952; C. C. Balch, unpublished). The samples were best taken in a small glass jar, the top of which was closed by the operator's hand during insertion and removal and which was not filled until its opening had been brought close to the reticulo-omasal orifice. In Exps. I and 2 the samples were taken from the same point by means of a vacuum sampling device operated by a milking-machine pump. This procedure was discontinued because of the risk of drawing materials such as sand from the lower parts of the reticulum. About $600 \mathrm{ml}$. were withdrawn in the jar at each sampling and were divided equally, one sample being dried at $100^{\circ}$ and the other acidified with sulphuric acid and stored for nitrogen determination. The analyses were made on the bulked samples for the whole period.

Exp. 5 included duplicate measurements in successive periods of 5 days, and is reported in detail to demonstrate the magnitude of period-to-period variation.

In the faecal-digestibility trials accompanying each attempt to determine the extent of digestion in the reticulo-rumen, it was found that the amount of lignin in the faeces was not always the same as the amount digested (see p. 218). In calculating the digestibility coefficients for the reticulo-rumen it has been assumed that the weight of lignin leaving the reticulo-rumen was the same as the weight found in the faeces. This calculation was made for each nutrient by means of the following modification of the equation on p. 213:

Digestibility in reticulo-rumen $(\%)$

$$
=100-\left(100 \times \frac{\text { nutrient in digesta }(\%)}{\text { lignin in digesta }(\%)} \times \frac{\text { lignin in faeces }(\mathrm{lb} .)}{\text { nutrient in food (lb.) }}\right) .
$$

\section{RESULTS}

\section{Between-cow and between-period variation}

Before reporting the results of the five experiments, it is desirable to consider the degree to which values for the apparent digestibility of a diet in the reticulo-rumen could be reproduced in different trials and animals. The best data for this purpose relate to Exp. 5. In Table 2 are given the coefficients of apparent digestibility in the reticulo-rumen for each of the four cows in the two 5-day periods of the experiment. These values showed a considerable similarity both within and between cows and it is interesting that markedly aberrant values for dry matter, nitrogen-free extract and crude fibre, for example in cow $\mathrm{K}$ in period $b$, tended to be reflected in the faecaldigestibility coefficients. The mean differences between the values for each 5 -day period in individual cows and, in parentheses, corresponding values for the faecal coefficients were: dry matter $2.7 \%(2.6 \%)$ crude protein $12.8 \%(3.4 \%)$, ether extract $7 \cdot 2 \%(7 \cdot 2 \%)$, nitrogen-free extract $3 \cdot 4 \%(3 \cdot 0 \%)$, crude fibre $6 \cdot 2 \%(3 \cdot 4 \%)$ and ash 
$174 \%(4.0 \%)$. In view of the short length of the periods this degree of agreement seems satisfactory, but in future experiments it would be as well to extend collection periods to at least 10 days. The mean values for each of the cows in the combined periods of 10 days in Exp. 5 are given in Table 3. The range was: dry matter from 26 to $31 \%$, crude protein from -9 to $+1 \%$, ether extract from 40 to $52 \%$, nitrogen-free extract from 43 to $47 \%$, crude fibre from 22 to $32 \%$ and ash from -92 to $-73 \%$. Thus the differences between individual cows receiving the same diet were not large.

Table 2. Exp. 5, part 1. Apparent digestibility in the reticulo-rumen, in each 5-day period of determination ( $a$ and $b$ ), of the diet of hay and beet pulp

\begin{tabular}{|c|c|c|c|c|c|c|c|}
\hline \multirow[b]{2}{*}{ Cow } & \multirow[b]{2}{*}{ Period } & \multicolumn{6}{|c|}{ Apparent digestibility coefficient $(\%)$} \\
\hline & & $\begin{array}{c}\text { Dry } \\
\text { matter }\end{array}$ & $\begin{array}{l}\text { Crude } \\
\text { protein }\end{array}$ & $\begin{array}{l}\text { Ether } \\
\text { extract }\end{array}$ & $\begin{array}{l}\text { Nitrogen- } \\
\text { free extract }\end{array}$ & $\begin{array}{l}\text { Crude } \\
\text { fibre }\end{array}$ & Ash \\
\hline D. 15 & $\begin{array}{l}a \\
b\end{array}$ & $\begin{array}{l}30 \cdot 1 \\
32 \cdot 7\end{array}$ & $\begin{array}{r}8 \cdot 5 \\
-7 \cdot 3\end{array}$ & $\begin{array}{l}4 I \cdot 7 \\
38 \cdot 3\end{array}$ & $\begin{array}{l}43 \cdot 7 \\
48 \cdot 8\end{array}$ & $\begin{array}{l}33.4 \\
30.7\end{array}$ & $\begin{array}{l}-85 \cdot 7 \\
-60 \cdot 2\end{array}$ \\
\hline $\mathrm{K}$ & $\begin{array}{l}a \\
b\end{array}$ & $\begin{array}{l}29 \cdot 2 \\
23 \cdot 6\end{array}$ & $\begin{array}{r}-6.3 \\
-11 \cdot 1\end{array}$ & $\begin{array}{l}49 \cdot I \\
54 \cdot 8\end{array}$ & $\begin{array}{l}46 \cdot 9 \\
42 \cdot 2\end{array}$ & $\begin{array}{l}29 \cdot 6 \\
17 \cdot 1\end{array}$ & $\begin{array}{l}-97 \cdot 7 \\
-85 \cdot 6\end{array}$ \\
\hline W. 22 & $\begin{array}{l}a \\
b\end{array}$ & $\begin{array}{l}28 \cdot 3 \\
30 \cdot 2\end{array}$ & $\begin{array}{r}5.4 \\
-r 45\end{array}$ & $\begin{array}{l}54 \cdot 5 \\
40 \cdot 6\end{array}$ & $\begin{array}{l}45 \cdot 8 \\
48 \cdot 2\end{array}$ & $\begin{array}{l}26 \cdot 6 \\
29 \cdot 4\end{array}$ & $\begin{array}{l}-97 \cdot 1 \\
-80 \cdot 3\end{array}$ \\
\hline L. 32 & $\begin{array}{l}a \\
b\end{array}$ & $\begin{array}{l}26 \cdot 4 \\
27 \cdot 1\end{array}$ & $\begin{array}{r}-4 \cdot 4 \\
6.1\end{array}$ & $\begin{array}{l}52 \cdot 0 \\
46 \cdot 4\end{array}$ & $\begin{array}{l}42 \cdot 7 \\
44^{\circ} \circ\end{array}$ & $\begin{array}{l}25.7 \\
19.0\end{array}$ & $\begin{array}{l}-89 \cdot 6 \\
-74 \cdot 3\end{array}$ \\
\hline & Mean* & $28 \cdot 4$ & $-3 \cdot 0$ & $47 \cdot 2$ & $45^{*} 3$ & $26 \cdot 4$ & $-83 \cdot 8$ \\
\hline & Meant & $29 \cdot 5$ & $-I \cdot 6$ & $49^{\circ} \circ$ & $47 \cdot 3$ & $27 \cdot 6$ & $-82 \cdot 1$ \\
\hline
\end{tabular}

Arithmetical.

$\dagger$ Calculated on the assumption that the weight of lignin leaving the reticulo-rumen equalled the weight ingested (see this page).

\section{Effect of apparent digestion of lignin}

With relatively short collection periods, and especially when the diet contains little lignin, it is possible that the amount of lignin present in the gut at the beginning and end of the periods will vary slightly. Accumulations will be recorded as positive digestibility coefficients and any reduction in the amount present will appear as negative coefficients. It seems probable that the contents of the reticulo-rumen are more likely than the contents of the remainder of the gut to be affected by such smallscale increases or decreases in lignin content, and if digestion of lignin takes place the reticulo-rumen is the most likely site. Accordingly, it has been assumed that the amount of lignin found in the faeces during a collection period equalled the amount leaving the reticulo-rumen in that period. In Exps. I and 2 some of the digestibility coefficients for lignin (Table 3) were much larger than the mean values found by Balch et al. (1954), and in these instances markedly different values for digestion in the reticulo-rumen would have been obtained if it had been assumed that the amount of lignin leaving the reticulo-rumen equalled the amount consumed in the food. As shown in Table 2, the use of this alternative method would have exerted little effect on the mean values for Exp. 5 . 


\section{Apparent digestibility in the reticulo-rumen and in the remainder of the gut}

The values obtained in the five experiments are summarized in Table 3 as the apparent digestibility coefficients for $(a)$ the reticulo-rumen, and $(b)$ the remainder of the gut (hind gut). The latter value was obtained by subtracting the coefficient for the reticulo-rumen from that for the whole gut (faecal digestibility). In a more critical comparison it might have been wise to discard the values obtained when lignin recovery was not within 90-1 10\% of the intake, but since the values obtained appear to follow the general trends the expedient discussed in the previous paragraph appears to have been successful.

Dry matter. The range of apparent digestibility of dry matter in the reticulo-rumen was $26-62 \%$ and in the hind gut $12-34 \%$. With diets containing large amounts of concentrates a larger proportion of the total digestion tended to occur in the reticulorumen than with diets containing much hay or only hay. Grinding the hay appeared to increase the proportion digested in the reticulo-rumen. Explanations for these tendencies are apparent when the fractions making up the dry matter are considered.

Crude protein (nitrogen). In every observation the apparent digestibility of crude protein in the reticulo-rumen was always lower, and in the hind gut it was always higher than the corresponding value for dry matter. With diets rich in concentrates the values approached those for dry matter, but with diets mainly or entirely of hay the amount of crude protein leaving the reticulo-rumen appeared to be often at least as great as the amount ingested as food; the small negative values recorded in Exps. 2 and 5 suggested that the outflow exceeded the intake as food. Again, grinding the hay tended to increase the proportion digested in the reticulo-rumen.

Ether extract. In all except three instances the digestibility of this ill-defined fraction was greater in the reticulo-rumen than in the hind gut, and the negative values for the hind gut observed in Exps. 1, 2 and 4, and especially in Exp. 5, suggested that during passage through the hind gut ether-extractable substances were added to the digesta in amounts that exceeded the amounts digested in this region.

Nitrogen-free extract. The clearest conclusion that can be drawn is that the nonfibrous carbohydrates were digested to a markedly greater degree in the reticulo-rumen $(43-76 \%)$ than in the hind gut $(7-22 \%)$. It is clear that the high apparent digestibility of the dry matter of diets rich in concentrates was due largely to the high digestibility of the nitrogen-free extract. The tendency for grinding to increase the proportion of the diet digested in the reticulo-rumen was again apparent although cow L. 32 in Exp. 4 was exceptional in showing virtually no change.

With this simple scheme of analysis no indication is given of the extent to which polysaccharides of microbial origin contributed to the nitrogen-free extract leaving the reticulo-rumen, and were digested in the hind gut.

Crude fibre. It was surprising to find that the amounts of crude fibre apparently digested in the reticulo-rumen did not always exceed those digested in the hind gut. As discussed previously (Balch et al. 1955), the small negative values found in period 2 of Exp. 3 were possibly the result of decreasing accumulation of crude fibre in the reticulo-rumen coupled with the well-known depressing effect of starch on the 


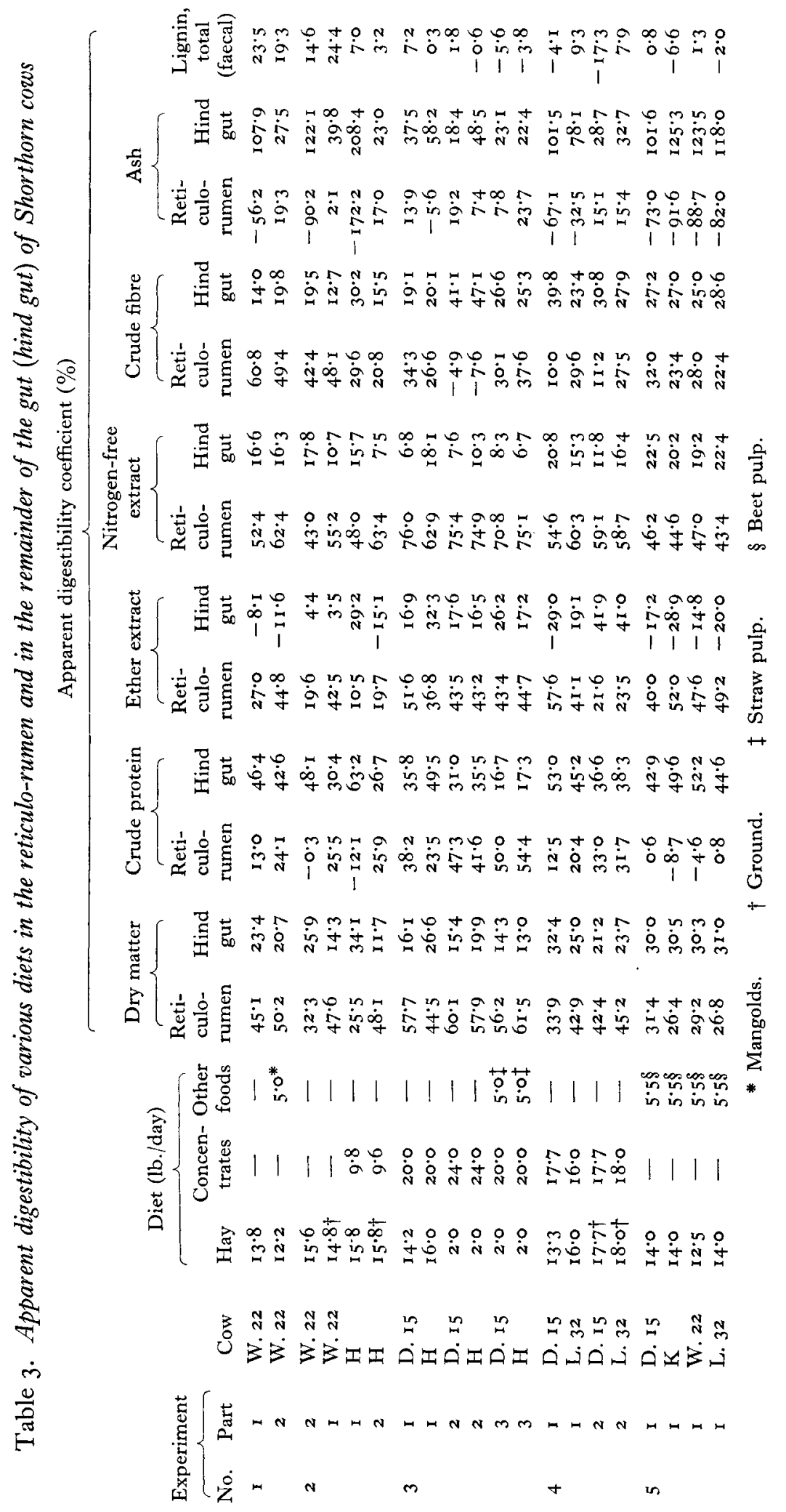


digestibility of fibre. The small amounts of digesta found in the reticulo-rumen of these cows at the end of the collection period support this theory. Whatever the explanation, the amounts concerned were very small (see below).

Introduction of concentrates in large amounts tended to lower the apparent digestibility of crude fibre in the reticulo-rumen, but grinding the hay appeared to exert no constant effect. With the diet of hay and beet pulp, in Exp. 5, the values for the reticulorumen were $22-32 \%$ and for the hind gut $25-29 \%$. Although the proportion apparently digested in the reticulo-rumen was surprisingly low, the consistency of the results encourages confidence in their reliability.

$A s h$. Values for this constituent were very variable and demonstrated that with it, more than with any other fraction, the results were influenced by processes additional to true digestion. Occasional negative values were found for the apparent digestion in the reticulo-rumen during each experiment and in every cow in Exp. 5. These are further instances of the amounts leaving the reticulo-rumen exceeding the amounts added. The coefficients for ash in the hind gut were all positive. The values for ash in the first two experiments, and especially for cow $\mathrm{H}$ in Exp. 2, may be spurious owing to unrepresentative sampling of digesta (see p. 217).

\section{Amounts of food constituents apparently digested in the reticulo-rumen and in the remainder of the gut}

The amount of the conventional fractions apparently digested in the two regions of the gut are given in Table 4 . These indicate that 4-16 lb. dry matter were digested daily in the reticulo-rumen and $2-9 \mathrm{lb}$. in the hind gut. The values for crude protein show that the occasional negative digestibility coefficients represented only very small amounts $(0.05-0.25 \mathrm{lb}$. daily). The nitrogen-free extract evidently accounted on the average for $80 \%$ of the dry matter apparently digested in the reticulo-rumen; the value for cow $\mathrm{H}$ in Exp. 2, part I, was clearly affected by the high ash content of the sample of digesta (see p. 2 I 7 ).

The amounts of crude fibre apparently digested in the reticulo-rumen were $0.4^{-}$ $2.8 \mathrm{lb}$. daily, with the exception of the very small negative values in part 2 of Exp. 3 . On average, crude fibre represented $13 \%$ of the dry matter apparently digested in the reticulo-rumen. In the hind gut $0 \cdot 6-\mathrm{I} \cdot 7 \mathrm{lb}$. were apparently digested daily.

The most interesting values for ash were obtained in Exp. 5 and suggested that the amount leaving the reticulo-rumen exceeded the input by $0 \cdot 7-0.9 \mathrm{lb}$. daily, all of which was absorbed in the hind gut.

\section{DISCUSSION}

The diets given in the five experiments were of widely differing types ranging from hay alone or supplemented only with mangolds or dried sugar-beet pulp to diets consisting of $24 \mathrm{lb}$. concentrates and only $2 \mathrm{lb}$. hay. They gave a wide range of intake of the conventional analytical fractions: the intake of crude protein varying from $I$ to $5 \mathrm{lb}$. daily, that of the nitrogen-free extract from 6 to $\mathrm{I} 8 \mathrm{lb}$. and that of the crude fibre from 2 to $6 \mathrm{lb}$. daily. An important constituent of the diets high in concentrates was the starch of flaked maize, which formed most of the 6-7 lb. starch consumed and 


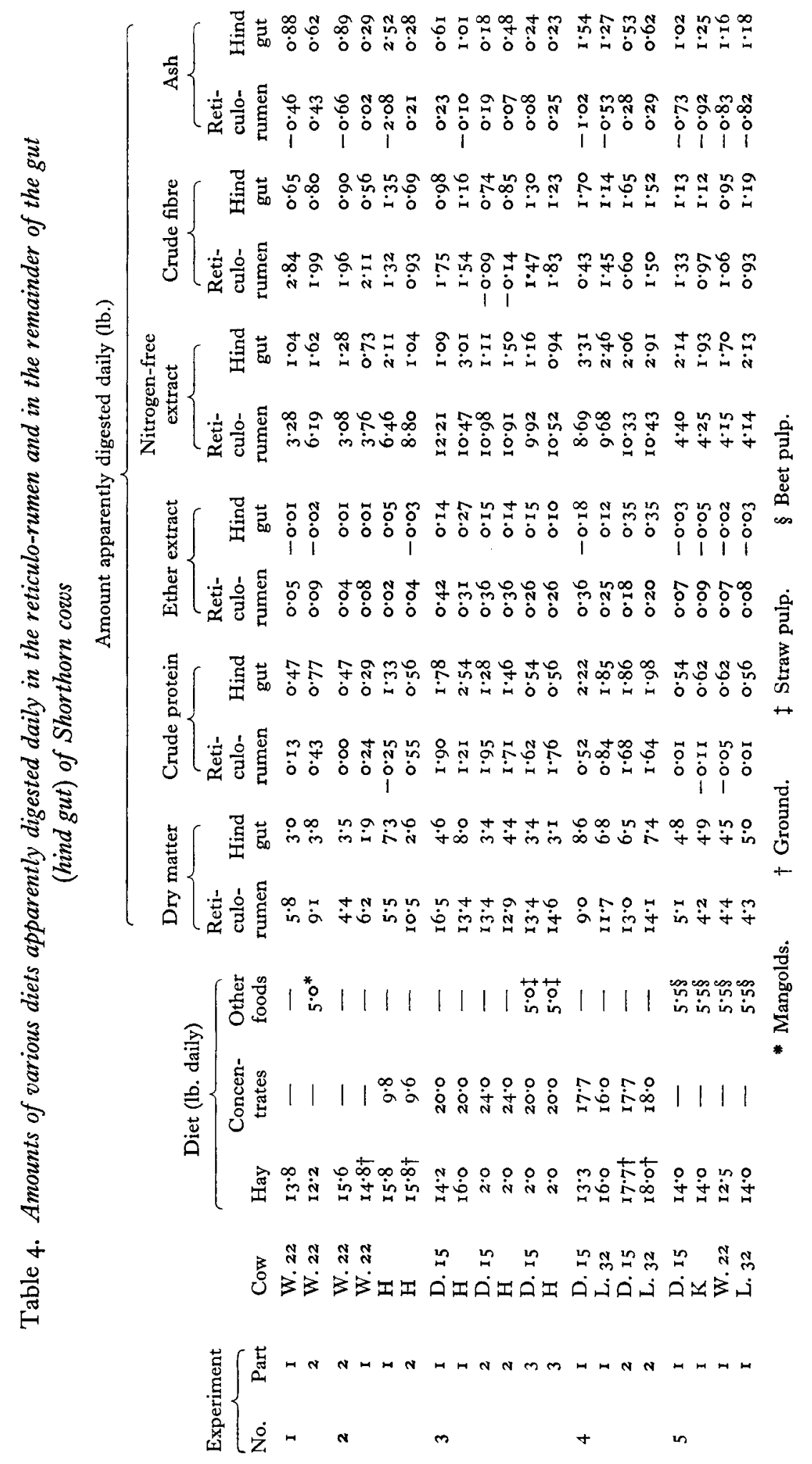


digested daily by the cows in parts 2 and 3 of Exp. 3. This aspect has been reported previously in relation to the production of volatile fatty acids in the reticulo-rumen and their effect on milk-fat percentage (Balch et al. 1955).

In the experiments now reported, $58 \%$ of the dry matter consumed by the cows was in the nitrogen-free extract fraction and $20 \%$ in the crude-fibre fraction. Thus carbohydrates constituted almost $80 \%$ of the intake. It is now widely recognized that complete breakdown of these substances in the reticulo-rumen will be to volatile fatty acids with the production of carbon dioxide, water and methane. Though it is likely that, by and large, an average particle of readily digested carbohydrate will be completely broken down during its sojourn in the reticulo-rumen, it is likely that some particles-particularly of the less digestible carbohydrates-will be swept from the reticulo-rumen in an altered state, but still not completely broken down to fatty acids. Some of the fatty acids will be absorbed directly from the reticulo-rumen through the epithelial lining, possibly being metabolized in the process, and a proportion must pass through the reticulo-omasal orifice. Since, however, with most diets the digesta found in the abomasum contain little volatile fatty acid, it seems likely that most of that passing through the orifice is absorbed in the omasum. In experiments described by Paloheimo et al. (1955) the total free and bound volatile fatty acids, calculated as acetic acid, varied in the contents of the abomasum, in five cows and two calves from 0.17 to $0.98 \%$ of the dry matter. Owing to the method of drying used in the preparation of my samples of digesta for analysis, any volatile fatty acids present in the samples would be lost. In consequence the crude fibre, nitrogen-free extract, and possibly the ether extract, recorded as being digested in the reticulo-rumen may include small amounts that were not in fact absorbed until farther along the digestive tract. This does not appear to be a serious drawback and could be readily overcome; it will not affect nitrogenous compounds or ash.

The results suggest that on average almost half $(43 \%)$ of the dietary dry matter was digested in the reticulo-rumen and that some $80 \%$ of this apparently digested dry matter was in the form of nitrogen-free extract and $13 \%$ was as crude fibre, representing $8 \mathrm{x}$ and $54 \%$ of the total (faecal) digestion of these fractions. Confirmation of these high values by a completely independent method would increase the importance attached to the reticulo-rumen as the major site of carbohydrate breakdown. By their somewhat different ratio technique Paloheimo et al. (1955) found that $85-9 \mathrm{I} \%$ of the total digestion of nitrogen-free non-lignin organic matter took place in the proventriculi. In Exp. 3 of those now reported, detailed analysis of the fibre fractions showed that the apparent digestibility in the reticulo-rumen of the cellulose resembled that of crude fibre, whereas that of the pentosans not in cellulose resembled that of the nitrogen-free extract. The starch was digested to the extent of $93-98 \%$ (Balch et al. I955).

There is evidence (Balch, I950) that, in cows, undigested residues of concentrates leave the reticulo-rumen somewhat more rapidly than residues of hay. The differences were, however, not very large, and it can be assumed that a given 'food point' (Mäkelä, I 956) is likely to remain in the reticulo-rumen only a few hours less if it is of concentrate origin than if it is derived from hay. It seems reasonable in consequence 
to expect the more digestible carbohydrates in concentrates to be broken down to a greater extent than the fibrous carbohydrates in hay, and clearly in a given particle of hay fibrous materials may be expected to resist digestion longer than other carbohydrates. Thus, although the digestion of fibre constitutes one of the main functions of the reticulo-rumen, it seems likely that other carbohydrates, such as those contained in the nitrogen-free extract, are digested there to a very much greater degree. The observed digestibility coefficients for crude fibre ranged from -8 to $+6 \mathrm{r} \%$ and for nitrogen-free extract from 43 to $76 \%$. It should, however, be noted that the presence of starch is known to depress the digestion of crude fibre by ruminants (Head, 1953), and the values obtained in my experiments suggest that when concentrates formed a large part of the diet the proportion of crude fibre digested in the reticulo-rumen was lowered and the proportion digested elsewhere in the gut was somewhat raised. With a few diets consisting entirely of hay the apparent digestibility of crude fibre in the reticulo-rumen was $42-61 \%$ and for the hind gut $13-20 \%$. With diets containing concentrates or beet pulp comparable values were $10-38 \%$ and $16-40 \%$ (excluding values for part 2 of Exp. 3). The accuracy of these values as measures of the balance of outflow from the reticulo-rumen over the intake as food must depend entirely on the success of the new technique described here in obtaining a representative sample of the digesta leaving the reticulo-rumen.

In Exps. I-4 the digesta lying close to the reticulo-omasal orifice were sampled at a constant rate of once every $3 \mathrm{~h}$ from the beginning of one meal to the beginning of the next meal $\mathrm{i} 2 \mathrm{~h}$ later, on the assumption that the average rate of flow of digesta through the orifice was relatively constant throughout the $12 \mathrm{~h}$. In the time between Exps. 4 and 5 , however, evidence was collected that the rate was approximately doubled during periods of eating. Since an equal volume was taken at each sampling the higher drymatter percentage of digesta close to the orifice during eating would cause a higher representation of these digesta in the composite sample, but in Exp. 5 twice the number of samples were taken during eating to compensate for the increased rate of passage. The effect of insufficient sampling during eating would probably be that the values obtained for the digestibility of nitrogen-free extract in the reticulo-rumen were slightly high, whereas those obtained for crude fibre were slightly low. Further consideration of this point is of little use unless supported by values for the changes with time after feeding of the composition of digesta from the region of the reticulo-omasal orifice or by the results of a completely independent method of determination. The method would be clearly at fault if duplicate readings on the same cow were not similar or if values for different cows on the same diet were markedly different. The results, particularly for Exp. 5, are encouraging in this respect, although it would evidently be advisable to make collection periods at least as long as the periods in normal digestibility trials.

The values for crude protein suggest that with the diets that contained either large amounts of concentrates in which groundnut cake was the major source of protein, or hay in a finely ground state, a considerable percentage (12-54) of the dietary nitrogen was absorbed from the reticulo-rumen. Subsequent work with cows receiving diets containing large amounts of the same concentrate mixture has shown that the 
production of ammonia in the reticulo-ruminal contents was unusually high some hours after feeding when the effect of starch in depressing the level of ammonia had diminished owing to digestion of the starch (Head, 1956). In contrast, the levels of ammonia found with the diet given in Exp. 5 were extremely low, and the apparent digestibility coefficients for crude protein were very low or slightly negative. Since any nitrogen absorbed from the reticulo-rumen is likely to be in the form of ammonia, these observations on the concentration of ammonia in the reticulo-rumen lend support to the validity of the digestibility coefficients. A digestibility coefficient of zero for crude protein implies that the amount of nitrogen leaving the reticulo-rumen was equal to the amount supplied in the food and that any absorption of nitrogen was balanced by secretion of nitrogenous compounds in the saliva. It was evidently so in Exp. 5, but the suggestion that up to $50 \%$ of the nitrogen of some of the other diets can be absorbed from the reticulo-rumen probably in the form of ammonia would, if confirmed, be of great practical importance, since absorbed ammonia represents an almost complete loss to the animal. Evidence for even larger losses of nitrogen from the whole stomach of the sheep was reported in a recent communication by Gray \& Pilgrim (1956). Applying the lignin-ratio technique to samples of digesta obtained from the abomasum, omasum and rumen after slaughter, these workers found that the proportion of the dietary nitrogen reaching the abomasum was only about $40 \%$ with good-quality lucerne hay and about $60 \%$ with a mixture of wheaten hay and lucerne hay. With a mixture of wheaten hay and straw the amount of nitrogen reaching the abomasum apparently exceeded the amounts given with the food, which may have been analogous to the situation observed in my Exp. 5. The lack of any marked rise and fall in the ratio of nitrogen to lignin in samples of abomasal contents from sheep killed at intervals after feeding, suggests that, at least with diets of roughage alone, sampling even at a rate quite unrepresentative of the rate of flow of digesta would not give a very marked bias to a composite sample of the digesta passing through the reticulo-omasal orifice.

The negative values now obtained for the apparent digestibility of ether extract in the hind gut presumably represent additions to the digesta of ether-extractable substance in the epithelial debris and digestive secretions. With non-ruminant animals there is considerable evidence to suggest that little of the faecal fat is of dietary origin. A similar situation possibly exists in the ruminant.

With the ash the opposite was observed. The amounts lost by absorption from the reticulo-rumen sometimes appeared to be exceeded by the amount added from a nondietary source, presumably the saliva. Values for digestibility of ash are obviously only balances and give no indication of the relative rates of addition and absorption.

In view of widespread objection to the use of lignin as a marker in digestibility studies it should be mentioned here that in Exps. I, 2 and 5 and in one further trial (Balch, Reid \& Stroud, 1957) it was found that attempts to use chromium sesquioxide as a marker with samples collected from near the reticulo-omasal orifice, in the way that lignin has been used in the present experiments, failed. In all instances the ratio of $\mathrm{Cr}_{2} \mathrm{O}_{3}$ to dry matter in the digesta samples was lower than in either the food or the faeces, evidently owing to a rapid passage of $\mathrm{Cr}_{2} \mathrm{O}_{3}$ from the reticulo-rumen in the 
first half-hour or so after its administration (Balch et al. 1957). Sperber \& Hyden (1952) have successfully used liquid polyethylene glycol of high molecular weight as a marker in studies on the omasum. Its value for the present purpose seems doubtful, however, in view of the likelihood that water is removed from the reticulo-rumen at a faster rate than are solid digesta. Sperber, Hyden \& Ekman (I953) believe that polyethylene glycol may be used for assessing the flow of water and dissolved substances from the reticulo-rumen to the omasum, which would make a valuable addition to the lignin-ratio technique.

In conclusion, it should be affirmed that the use of the lignin-ratio technique with the new method for obtaining representative samples of digesta leaving the reticulorumen is feasible and has given promising results. If these results can be confirmed by an independent method, such as the use of abomasal fistulas and more specific analytical fractions, they should demonstrate that the extreme importance of the reticulorumen in carbohydrate degradation and as a site of protein loss with certain diets has not been exaggerated. Until such confirmation is obtained it is necessary that the values be regarded as tentative estimates.

\section{SUMMARY}

I. In five experiments Shorthorn cows with rumen fistulas received a wide range of diets varying from all-hay to $24 \mathrm{lb}$. concentrates with $2 \mathrm{lb}$. hay daily. Digestibility trials were conducted with each diet, and while these were in progress estimates were obtained of the extent of digestion in the reticulo-rumen and in the remainder of the gut (hind gut).

2. To determine digestibility coefficients for the reticulo-rumen the lignin-ratio technique was applied to composite samples of digesta taken in the close proximity of the reticulo-omasal orifice at frequent intervals throughout periods of $5^{-12}$ days. It is claimed that the composite samples were representative of the digesta passing through the orifice, but until such samples are proved representative, or the method is otherwise checked, the resulting values have to be regarded as tentative. It is stressed that with many dietary constituents apparent digestibility coefficients for the reticulo-rumen will represent the balance of intake over outflow, and that in addition to breakdown and absorption the processes of salivary secretion and microbial synthesis may affect the balance.

3. Provided samples were taken over periods of about 10 days it was found possible to obtain reasonable agreement between duplicate determinations on one animal or between different animals on the same diet.

4. On average $58 \%$ of the dry matter consumed by the cows was in the form of nitrogen-free extract and $20 \%$ as crude fibre. The range of apparent digestibility of dry matter in the reticulo-rumen was from 26 to $62 \%$ and in the hind gut from 12 to $34 \%$. On average for the diets studied $43 \%$ of the dietary dry matter was apparently digested in the reticulo-rumen, about $80 \%$ of the digested dry matter being in the form of nitrogen-free extract and $\mathrm{I}_{3} \%$ as crude fibre. Thus the proportion of the dry matter apparently digested in the reticulo-rumen was much higher with diets rich in concentrates than with those consisting mainly or entirely of roughage. 
5. With diets consisting mainly of roughage and containing only small amounts of protein the apparent digestion of crude protein (nitrogen) in the reticulo-rumen was low, suggesting that there was little or no absorption of nitrogen from the reticulorumen. With diets containing large amounts of concentrates and protein in the form of groundnut cake there was evidence of a considerable loss (12-54\%) of the dietary nitrogen by absorption from the reticulo-rumen.

6. It is concluded that the method is a feasible means of obtaining digestibility coefficients for the reticulo-rumen. If confirmed by independent means the results would show that the extreme importance of the reticulo-rumen in carbohydrate degradation and as a site of protein loss has not been exaggerated.

The extensive analyses involved in these experiments were made by Dr D. A. Balch and Dr M. J. Head to whom I am most grateful. I wish also to thank Mr V. W. Johnson and Mrs Jill Roy for their assistance with practical aspects of the experiments and the computation of results.

\section{REFERENCES}

Armitage, E. R., Ashworth, R. de B. \& Ferguson, W. S. (1948). Y. Soc, chem. Ind., Lond., 67, 241.

Balch, C. C. (1950). Brit. F. Nutr. 4, 36r.

Balch, C. C. (1952). Brit. F. Nutr. 6, 366.

Balch, C. C., Balch, D. A., Bartlett, S., Bartrum, M. P., Johnson, V. W., Rowland, S. J. \& Turner, J. (1955). F. Dairy Res. 22, 270.

Balch, C. C., Kelly, A. \& Heim, G. (195r). Brit. F. Nutr. 5, 207.

Balch, C. C., Reid, J. T. \& Stroud, J. (1957). Brit. J. Nutr. II, I84.

Balch, D. A., Balch, C. C. \& Rowland, S. J. (1954). F. Sci. Fd Agric. 12, 584.

Gray, F. V. (1947). F. exp. Biol. 24, 15.

Gray, F. V. \& Pilgrim, A. F. (1956). Nature, Lond., r78, 94.

Hale, E. B., Duncan, C. W. \& Huffman, C. F. (1940). F. Dairy Sci. 23, 953.

Hale, E. B., Duncan, C. W. \& Huffman, C. F. (r947a). F. Nutr. 34, 733.

Hale, E. B., Duncan, C. W. \& Huffman, C. F. (1947b). F. Nutr. 34, 747.

Head, M. J. (1953). F. agric. Sci. 43, 281 .

Head, M. J. (1956). Unpublished.

Mäkelä, A. (1956). Suom. Maataloust. Seur. Fulk. no. 85.

Paloheimo, L., Mäkelä, A. \& Salo, M.-L. (1955). Maataloust, Aikakausk. 27, 70.

Phillipson, A. T. (1952). F. Physiol. 116, 84 .

Sperber, 1. \& Hyden, S. (1952). Nature, Lond., r69, 587.

Sperber, I., Hyden, S. \& Ekman, J. (1953). LantbrHögsk. Ann. 20, 337. 